\title{
BRITISH NATIONAL BIOGRAPHY AND GLOBAL BRITISH LIVES: FROM THE DNB TO THE ODNB AND BEYOND? ${ }^{1}$
}

\section{DAVID CANNADINE}

The Oxford Dictionary of National Biography $(O D N B)$, like the original Dictionary of National Biography $(D N B)$ from which it has evolved and developed, has rightly been described as a recent culmination of several centuries of collective biographical efforts, which have taken three distinct and different forms. The oldest is group biography, which was of classical origins, was widely practised in Renaissance Italy, and thrived in eighteenth-century Britain, where many professionals sought to establish their own occupational pedigrees, and where competing religious denominations sought to create their own canon of heroes and martyrs. The second was so-called 'universal biography', which was an essentially Enlightenment enterprise, as philosophes and polymaths produced multivolume works aspiring to contain the lives of all the notable people who had ever lived. The third genre was national biography, which flourished across much of the Western world during the nineteenth century, and it is scarcely a coincidence that this was also the first European

1 I am, as ever, deeply grateful to former and present colleagues at the $O D N B$ for their help and support in the preparation of this essay: to Jo Payne, Philip Carter, Mark Curthoys and Alex May; and to the writings of previous editors, the late Colin Matthew, Sir Brian Harrison, and Lawrence Goldman. 
era of nationalist sentiment and state creation. Many of these works, most notably in Germany after its unification in 1870, were sponsored by government, which saw the production of such biographical dictionaries, commemorating great figures from an heroic (and sometimes mythical) national past, as a way of promoting unity, identity, consciousness, and pride across the varied regions, languages, religions, and ethnicities which in reality made up many of these new countries. Yet from a different perspective, such national biographies were also regarded as progressive and improving agents of moral uplift, public education, and individual entertainment—as, indeed, was the nation state itself. ${ }^{2}$

Like the National Portrait Gallery (founded in 1856), and the Blue Plaques scheme for London (begun 10 years later), the original $D N B$ (of which the first instalment appeared late in 1884, although it was dated 1885) may easily be presented as a classic instance of national self-regard, Victorian hero worship, and British patriotic veneration: in sum as a sort of 'Westminster Abbey in print'. ${ }^{3}$ Yet in none of these three cases was this the whole truth of things, and perhaps least of all in regard to the $D N B .{ }^{4}$ For unlike many such works that were being produced on the continent, it was a private rather than a state-sponsored enterprise, and if its begetter and publisher, George Smith, had had his way, the result would have been a much more wide-ranging Dictionary of Universal Biography, which would have harked back to those earlier Enlightenment publications, suffused with the ideals of internationalism and cosmopolitanism. Indeed, it was only on further reflection, and following the advice of his friend Leslie Stephen, who would become the DNB's founding editor, that

2 Keith Thomas, Changing Conceptions of National Biography: The Oxford DNB in Historical Perspective (Cambridge: Cambridge University Press, 2005), 2-21. doi.org/10.1017/CBO97805 11497582; Colin Matthew, 'Dictionaries of National Biography', in National Biographies and National Identity: A Critical Approach to Theory and Editorial Practice, eds Iain McCalman with Jodi Parvey and Misty Cook (Canberra: Humanities Research Centre, The Australian National University, 1996), 3-4.

3 David Amigoni, 'Life Histories and Cultural Politics of Historical Knowing: The Dictionary of National Biography and the Late Nineteenth-Century Political Field', in Life and Work History Analyses: Qualitative and Quantitative Developments, ed. Shirley Drex (London: Routledge, 1991), 146, 163; David Amigoni, Victorian Biography: Intellectuals and the Ordering of Discourse (Hemel Hempstead: Harvester Wheatsheaf, 1993), 180, note 27; Iain McCalman, 'Introduction', in McCalman with Parvey and Cook, National Biographies and National Identity, ii, iv.

4 David Cannadine, The Pleasures of the Past (London: Collins 1989), 275-84; David Cannadine, National Portrait Gallery: A Brief History (London: National Portrait Gallery, 2007), 10-21; Emily Cole, 'Introduction', in Lived in London: Blue Plaques and the Stories Behind Them, ed. Emily Cole (London: Yale University Press and English Heritage, 2009), 1-11. 
Smith narrowed down the scope of his multivolume publishing venture from global biography to national coverage. But Stephen's concern about Smith's original project was practical anxiety about its manageability, rather than chauvinistic disappointment at its lack of patriotism; indeed, one of the early names that was considered for what became the $D N B$ was simply 'the new biographical dictionary'. And although the years during which the Dictionary appeared, from 1884 to 1900, were a time of unprecedented British overseas expansion and high Tory imperialism, its overall tone was documentary rather than celebratory, and, as befitted a multiauthored work, it displayed not only 'tranquil consciousness of Britain's world superiority', but also an element of fin-de-siècle cultural pessimism. Indeed, according to F. W. Maitland, the $D N B$ reflected more the confusion than the confidence of what he termed the 'national mind'.

Moreover, from the very beginning of the project, Stephen had disdained eulogy and hero-worship for $D N B$ entries, urging contributors to eschew rhetoric, sentiment, and panegyric. As one of his colleagues later put it, the preferred style of the contributions was best summarised in the phrase 'no flowers by request', while some of them have rightly been described as 'remarkably disrespectful and at times rude'. ${ }^{6}$ Stephen also settled on a brilliantly ambiguous title for the Dictionary, which put the adjective 'national' at the very centre of the enterprise, even as he refused to state precisely what, or where, or when, the 'nation' that was to be thus biographied had been, or what or where it was now. And since there was no preface or introduction to the first volume, setting out the aims or scope of the work, this meant the $D N B$ asserted nationality but carefully avoided defining it', either in terms of identities or geographies. ${ }^{7}$ This in turn meant that the criteria for inclusion were 'fluid and pragmatic', rather than rigid and confining, and as a result many of the original entries (as was also the case with the Blue Plaques scheme) recognised British nationals who had been active abroad, and foreign nationals who had played some part in British life. Indeed, neither the DNB's first article (on the French

5 Thomas, Changing Conceptions of National Biography, 8-9, 26; Lawrence Goldman, 'A Monument to the Victorian Age? Continuity and Discontinuity in the Dictionaries of National Biography, 18822004', Journal of Victorian Culture 11, no. 1 (2006): 113-14, 129-30, note 53. doi.org/10.3366/jvc. 2006.11.1.111; Frederick William Maitland, The Life and Letters of Leslie Stephen (London: Duckworth, 1906), 368.

6 Matthew, 'Dictionaries of National Biography', 7; H. C. G. Matthew and B. Harrison, 'Introduction and Other Preliminary Pages [to the $O D N B$ ]', issued separately (Oxford: Oxford University Press, 2004), x.

7 Matthew, 'Dictionaries of National Biography', 4; Matthew and Harrison, 'Introduction and Other Preliminary Pages’, viii. 
Protestant minister and writer, Jacques Abbadie, 1654?-1727), nor its penultimate entry (on the Dutch soldier and diplomat, Wilhelm Zuylestein, 1645-1709), was devoted to a person born in the British Isles; both of them had only later settled there. ${ }^{8}$ Such an imaginative and integrative policy on inclusion also fitted well with the libertarian, free-trading, and internationalist outlook that was prevalent among late Victorian Liberals, of whom Stephen was undoubtedly one (even though he would split from the party when Gladstone took up Home Rule). ${ }^{9}$

As the original 63 volumes of the DNB appeared, responses to Stephen's capacious inclusionary criteria were mixed. Some commentators, such as Professor Richard Copley Christie, writing in the Quarterly Review in 1887, applauded the fact that the entries in the Dictionary 'illustrate the cosmopolitan character of our nation'. ${ }^{10}$ But there were also critics, including an anonymous writer in the Athenaeum, in 1889, who could not understand why 'complete foreigners, such as De Baan the painter and some of the Dillons, are included'. ${ }^{11}$ Others acclaimed the DNB for reasons that would have been anathema to Stephen and Smith, regarding its successful completion, and on schedule, as well as its funding by a private publishing enterprise rather than with any support from the state, as an impressive indication of the very national superiority that they themselves had disdained. Another writer in the Athenaeum claimed that 'our British lexicographers have had the satisfaction of administering a handsome beating to their most formidable competitors, the Germans. ${ }^{12}$ Sidney Lee, who had followed Stephen as full-time editor in 1891, but who was less cosmopolitan and more chauvinistic in his outlook, took a similar view, placing the $D N B$ project explicitly within the context of such fin-de-siècle international rivalries, and declaring it a far more 'earnest endeavour' to satisfy 'the just patriotic instinct' of the 'British and Irish race' than the equivalent attempts in 'Germany, Holland, Belgium,

8 Matthew, 'Dictionaries of National Biography', 17; H. C. G. Matthew, Leslie Stephen and the New Dictionary of National Biography (Cambridge: Cambridge University Press, 1997), 36; Goldman, 'Monument to the Victorian Age?', 114.

9 Goldman, 'Monument to the Victorian Age?', 115.

10 R. Copley Christie, 'DNB vols 1-10', Quarterly Review 164 (1885): 367.

11 Unsigned review of DNB vols 14-18, Athenaeum, 20 April 1889, 500.

12 Athenaeum, 14 July 1900, 45. Quoted in Robert Faber and Brian Harrison, 'The Dictionary of National Biography: A Publishing History', in Lives in Print: Biography and the Book Trade from the Middle Ages to the 21st Century, eds Robin Meyers, Michael Harris, and Giles Mandelbrote (London: Oak Knoll Press and the British Library, 2002), 172; Goldman, 'Monument to the Victorian Age?', 116. 
Austria, and Sweden. ${ }^{13}$ And with the publication of the twentieth-century Supplements, covering the more recently deceased, the $D N B$ did become what Matthew would later describe (and regret) as 'a sort of establishment roll-call of national pre-eminence', to the exclusion of other different and more varied lives. ${ }^{14}$

Yet this was undoubtedly an aberration from the broader original remit that had been set by Smith and Stephen. To be sure, the original $D N B$ was conspicuously lacking in entries on entrepreneurs (despite the fact that it was privately funded by a publisher), and also on women (for which the more than 90,000-word entry on Queen Victoria, which appeared in the first supplement, scarcely atoned). The nation that was being biographied was overwhelmingly male, not female, but the men were rarely businessmen (or trades union leaders), while those Britons who worked in Europe were largely ignored. ${ }^{15}$ On the other hand, Stephen's $D N B$ had accepted entries on 'second rate people' and 'obscure names'; it included lives of criminals, highwaymen, brothel-keepers, contortionists, gamblers, journalists, and actors; and one of its most striking entries was the 3,000-word biography of the eighteenth-century, French-born, transvestite, the Chevalier d'Eon. ${ }^{16}$ Moreover, the extended chronological span meant the $D N B$ encompassed significant periods of Roman, AngloSaxon, Danish, Norman, and Angevin dominion across much of the British Isles. From the outset, the Dictionary also included many lives, not only from England, but also from the separate nations of Ireland and Scotland (although less so from Wales), from the composite Kingdom of Great Britain, and from the United Kingdom of Great Britain and Ireland. (As a Liberal-turned-Unionist, Stephen was especially eager to integrate the history of Ireland into British national life, and all the leaders of the Irish Rebellion of 1798 were given entries. $)^{17}$ And the $D N B$ also paid heed to the dramatic expansion of British rule overseas, especially the

13 S. Lee, 'The Dictionary of National Biography: A Statistical Account', preface to Dictionary of National Biography, vol. 63, Wordsworth-Zuylestein (London: Smith, Elder and Co., 1900), lxii.

14 Lee, 'A Statistical Account', $x$-xi, xxii; Brian Harrison, 'Comparative Biography and the DNB', Comparative Criticism 25 (2004): 11-12; Matthew and Harrison, 'Introduction and Other Preliminary Pages', vii.

15 Matthew, 'Dictionaries of National Biography', 8-11; Matthew, Leslie Stephen and the New Dictionary of National Biography, 14-19, 31.

16 Matthew, Leslie Stephen and the New Dictionary of National Biography, 13, 15, 18; Matthew, 'Dictionaries of National Biography', 8; Thomas, Changing Conceptions of National Biography, 23, 30; Goldman, 'Monument to the Victorian Age?', 117.

17 Matthew, Leslie Stephen and the New Dictionary of National Biography, 13; Matthew, 'Dictionaries of National Biography', 8. 
settlement colonies and India. Under these circumstances, it was not only prudent, but also unavoidable to keep the definition of English nationality or British identity or British imperial reach implicit and undefined.

When, more than a century later, Colin Matthew came to consider these matters afresh as editor-designate of the new Oxford Dictionary of National Biography, he was eager to return to, and even to extend, Stephen's original definition of nationality and criteria of inclusion. To be sure, he carried over into the new version all the names that had originally appeared in the old $D N B$. But in addition, the number of women included more than trebled, the number of businessmen and labour leaders more than doubled, and the twentieth-century entries covered a much broader range of activity than the original Supplements, including such icons of popular culture as footballers, comedians, and pop musicians, as well as individuals branded 'rakes', 'wastrels', and 'swindlers'. ${ }^{18}$ All subjects were chosen, not because they were deemed to be exemplary, and thus worthy of commemoration or celebration, or because they were exemplary instances of moral uplift, but on account of their historical importance and influence-whether for good or ill, or for good and ill. Matthew also adopted a working delineation of nationality which was 'fluid, practical and inclusive', and which followed and extended Stephen's original conception by treating the inhabitants of the British Isles and the British Empire as what he termed a 'nation-in-effect'. ${ }^{19}$ This, in turn, enabled him to emphasise the inherent pluralism of the constituent and changing nationalities of the British Isles and the British Empire, and to enhance the $O D N B$ 's coverage of people born, living in, working in, and sometimes leaving, Ireland, Scotland, Wales, the Isle of Man, and the Channel Islands; and he also gave greater prominence than the $D N B$ had done to those who went out to, or were born in, many of the British colonial territories, as well as continental Europe. ${ }^{20}$

18 Thomas, Changing Conceptions of National Biography, 35; Harrison, 'Comparative Biography and the DNB', 11; Goldman, 'Monument to the Victorian Age?', 119-20, 122-23.

19 Thomas, Changing Conceptions of National Biography, 34-42; Matthew, 'Dictionaries of National Biography', 17; Matthew, Leslie Stephen and the New Dictionary of National Biography, 35-37; Matthew and Harrison, 'Introduction and Other Preliminary Pages', viii.

20 Matthew and Harrison, 'Introduction and Other Preliminary Pages', viii. 
True to Stephen's founding vision, the original Dictionary had included many people who lived in British colonies, but who had never set foot in the British Isles. By allowing occasional entries on imperial and Commonwealth prime ministers and other leading figures, the $D N B$ Supplements had continued this earlier practice, albeit diminishingly so, and largely confining themselves to the colonies of settlement, namely Australia, Canada, New Zealand, and South Africa, as well as the Indian Empire. ${ }^{21}$ Matthew included all these colonial figures in the $O D N B$, and in assessing the claims of further potential entrants from the greater British overseas world, he was influenced by the extent to which, as he put it in another pragmatic and flexible working definition, they were 'known to Whitehall', as (for example) ruling chiefs, or British proconsuls, or nationalist leaders. On this basis, he increased the coverage of men and women who had lived in the former settlement colonies and South Asia, and he extended the 'known-to-Whitehall' principle to excolonial territories elsewhere in the British Empire, especially to other parts of Africa and to the Caribbean. He gave particular attention to those politicians who agitated and campaigned to end British colonial rule, and who oversaw the transition to independence, and who were thus the last imperial cohort who were 'known-to-Whitehall'. For the same reason, he also commissioned more articles on Irish lives for the years after 1922: partly because many nationalists had still been British subjects during the creation of the new, independent state, and partly because Eire formally remained a dominion within the British Empire until 1949. ${ }^{22}$

When the $O D N B$ was published in 2004, it was prefaced by the sort of introduction which Stephen had conspicuously refused to provide, and it offered a more extended definition of these 'pragmatic and flexible' concepts of nationality, noting that the Dictionary included

people who were born and lived in the British Isles, people from the British Isles who achieved recognition in other countries, people who lived in territories formerly connected to the British Isles at a time when they were in contact with British rule, and people born elsewhere who settled in the British Isles for significant periods or whose visits enabled them to leave a mark on British life. ${ }^{23}$

21 Harrison, 'Comparative Biography and the DNB', 5-6.

22 Matthew, Leslie Stephen and the New Dictionary of National Biography, 31-32; Matthew and Harrison, 'Introduction and Other Preliminary Pages', viii.

23 Matthew and Harrison, 'Introduction and Other Preliminary Pages', v. 
Hence the entry on the earliest identifiable subject in the $O D N B$, who was not included in the original Dictionary, namely the Greek explorer Pytheas (floruit, fourth century BCE), who was the author of the first known account of the British Isles by a foreign observer. Hence the 150 biographies of notable Roman officials who had been active in Britain during the period of occupation, along with entries on the Viking and Scandinavian invaders of the ninth and tenth centuries, and the warriors and notables who accompanied William the Conqueror in 1066. Hence also the entries on 800 prerevolutionary colonial Americans, whose lives had found no place in the original Dictionary, but who were undoubtedly 'known to Whitehall', and separate entries on the first four American presidents. Hence, too, the greatly increased coverage and range of the twentieth-century biographies. And hence the fact that more than one-tenth of all the subjects in the $O D N B$ had been born outside the British Isles. $^{24}$

Across the years since its original hard-copy publication, the $O D N B$ has routinely been described as providing 'the record of 60,000 men and women who shaped British history worldwide'. It is an apt summation of a collective biographical enterprise which in its scale and scope is national, yet also international, and in some ways world-encompassing. Many of the entries in the $O D N B$ are on Britons who might also be deemed to be 'world figures', and they pay appropriate attention to the extended reach and resonance of such individuals' lives and labours: the entry on Shakespeare, for example, includes sections on his reception and influence in America, Russia, and Japan; while the biography of John Locke stresses his significance for the development of political thought in many parts of the Western world and beyond. ${ }^{25}$ Other entries are on figures of major historical importance, but of foreign origin, who spent some time in Britain, among them Julius Caesar, Erasmus, Handel, Voltaire, George Washington, Benjamin Franklin, Mazzini, Marx, Gandhi, and King Farouk of Egypt—although many other such 'honorary Britons'

24 Harrison, 'Comparative Biography and the $D N B$ ', 6; Matthew and Harrison, 'Introduction and Other Preliminary Pages', viii; Goldman, 'Monument to the Victorian Age?', 115.

25 Peter Holland, 'Shakespeare, William (1564-1616)', Oxford Dictionary of National Biography, Oxford University Press, 2004; online edn, January 2013, accessed 16 August 2017. doi.org/10.1093/ ref:odnb/25200; J. R. Milton, 'Locke, John (1632-1704)', Oxford Dictionary of National Biography, Oxford University Press, 2004; online edn, May 2008, accessed 16 August 2017. doi.org/10.1093/ref: odnb/16885. 
were excluded. ${ }^{26}$ The 'worldwide, collaborative' nature of the $O D N B$, as a project by turns both national and international, is also reflected in the global profile of its authors, of whom 9,804 contributed to the 2004 publication, either as writers of new entries or as revisers of previous lives. Nearly three-quarters of them were based in the British Isles: 7,026 in the United Kingdom and 252 in Ireland. Another 2,526 contributors were recorded in 49 other countries: 1,396 in the United States, and 391 in Canada; 302 in Australia, and 88 in New Zealand; then 52 in Germany, 50 in France, 32 in South Africa, 31 in Italy, 16 in India, and 12 in Japan. A further 96 lived elsewhere in Europe, while 60 were living in 20 other countries in the rest of the world. ${ }^{27}$

The 60 volumes of the $O D N B$ included 50,113 substantive articles covering the lives of 54,922 people, all of them with a significant British connection, who had lived and died before 31 December 2000. But as always, the Dictionary remains a work in progress, and the continuing addition of new lives, whether from the distant past or of the more recently deceased, has been made much easier because the main form in which its text is now delivered and accessed is online. Since the beginning of 2005, the Dictionary has published updates in January, May, and September each year, and a significant number of these entries demonstrate the $O D N B$ 's continuing commitment to explore earlier transnational British lives which, thanks to the IT revolution, can now be reconstructed and pieced together in ways that would previously have been impossible. Some of them present the findings of long-running research projects to extend the $O D N B$ 's coverage in areas now deemed to be of great significance, including post-Reformation religious exiles leaving Protestant England for the comfort and reassurance of Catholic Europe; diplomatic representatives to London from the major continental courts, and visitors to Britain from much further afield; British merchants and traders working in the Middle East during the early modern period,

26 For example, Chateaubriand, King Louis-Philippe, Nathaniel Hawthorne, Giuseppe Garibaldi, Napoleon III, Robert Frost, and King Hussein of Jordan, all of whom also spent significant periods of time in Britain, have no entries: see James Raven, 'The Oxford Dictionary of National Biography: Dictionary or Encyclopaedia?', Historical Journal 50, no. 4 (2007): 1000-1001. doi.org/10.1017/ S0018246X07006474.

27 Matthew and Harrison, 'Introduction and Other Preliminary Pages', xiii, xviii; Goldman, 'Monument to the Victorian Age?', 127. 
and in China and Japan during the nineteenth century and beyond; the Pilgrim Fathers and the Founding Fathers of the American Republic; the biographies of settlers, traders, and investors in nineteenth-century Latin America, where there was a very strong British presence; and the lives of men and women from South Asia, Africa, and the Caribbean who since World War II have transformed the British nation into a multifaith, multiethnic, and multicultural society.

The $O D N B$ is also engaged in continuing efforts to explore international networks and cosmopolitan groups, among them the participants in the Third Crusade, those who took part in the Field of the Cloth of Gold, the Pilgrim Fathers, the Providence Island Company, the investors in the Darien scheme, the Anglo-South African 'Randlords', and the members of Lord Milner's 'Kindergarten'. Other lives that have recently emerged from research projects highlighting transnational themes are those of German- and East European-born directors and actors who were so important for the development of the British film industry from the 1920s. Many one-off transnational biographies have also been added to the online $O D N B$, among them overseas figures active in Britain, such as Theodoric Rood (floruit 1480-1484?), who was born in Germany and became the first named printer at the University of Oxford; John Blanke (floruit 1507-1512), a royal trumpeter, who was probably African-born, played for Henry VII and Henry VIII, and was the only identifiable black person portrayed in sixteenth-century British art; Pasqua Rosee (floruit 1652-1656), who grew up in the Greek community in Sicily, became a trader in Smyrna, and came to London in 1652 where he extolled the virtues of coffee and established London's first coffee house in the city; Francisco de Miranda (1750-1816), who originated in Venezuela, but spent much of his life in London, campaigning for Spanish American independence; Krishnabhabini Das (1864-1919), who was born in Bengal, came to England with her husband in 1876, and nine years later published Englande Bangamahila (A Bengali Lady in England) —an account of British manners based on her seven-year residence in London, much of it spent reading and researching in the British Library; and Georgi 
Markov (1929-1978), a Bulgarian writer and dissident, who moved to Britain in 1971 and worked for the British Broadcasting Corporation and Radio Free Europe, but was assassinated in London in 1978. ${ }^{28}$

At the same time, many new lives have been added to the $O D N B$ of Britons who were primarily active overseas rather than at home. William Weston (the precise dates of his birth and death are unknown) was a merchant and explorer, and the first Englishman to lead an expedition to North America, probably in $1499 .{ }^{29}$ Margaret Clement (1539-1612) belonged to a Roman Catholic family, and she was compelled, like many of her faith, to leave England because of her religious beliefs, and eventually became a prioress of St Ursula's, in Louvain. ${ }^{30}$ Henry Smeathman (1742-1786) was an explorer, who was born in Scarborough; he was a pioneer of African entomology and eventually settled in Sierra Leone. ${ }^{31}$ John Hughes (c. 1816-1889) grew up in Merthyr Tydfil, and became an ironmaster and engineer; he was later employed from the 1860s by the Russian Government, and took with him 100 specialist ironworkers and miners, who were mostly recruited from the industrial valleys of south Wales. ${ }^{32}$ William Lobb (baptised 1809, died 1863) was a Cornishman who devoted his life to collecting exotic plants; in southern Chile he found huge forests of Araucaria, which became popularly known in the

28 Kristian Jensen, 'Rood, Theodoric ( $f$. 1480-1484?)', Oxford Dictionary of National Biography, Oxford University Press, September 2014, accessed 16 August 2017. doi.org/10.1093/ ref:odnb/106749; Miranda Kaufmann, 'Blanke, John ( $f$. 1507-1512)', Oxford Dictionary of National Biography, Oxford University Press, October 2014; online edn, April 2016, accessed 16 August 2017. doi.org/10.1093/ref:odnb/107145; Brian Cowan, 'Rosee, Pasqua (fl. 1651-1656)', Oxford Dictionary of National Biography, Oxford University Press, September 2006; online edn, October 2007, accessed 16 August 2017. doi.org/10.1093/ref:odnb/92862; Karen Racine, 'Miranda, (Sebastián) Francisco de (1750-1816)', Oxford Dictionary of National Biography, Oxford University Press, May 2006, accessed 16 August 2017. doi.org/10.1093/ref:odnb/89687; Jayati Gupta, 'Das [née Sarbadhikari], Krishnabhabini (1864-1919)', Oxford Dictionary of National Biography, Oxford University Press, September 2012, accessed 16 August 2017. doi.org/10.1093/ref:odnb/102847; R. J. Crampton, 'Markov, Georgi Ivanov (1929-1978)', Oxford Dictionary of National Biography, Oxford University Press, May 2005; online edn, January 2007, accessed 16 August 2017. doi.org/10.1093/ ref:odnb/77434.

29 Evan T. Jones, and M. M. Condon, 'Weston, William (d. in or before 1505)', Oxford Dictionary of National Biography, Oxford University Press, May 2010, accessed 16 August 2017. doi.org/10.1093/ ref:odnb/101082.

30 Victoria Van Hyning, 'Clement, Margaret (1539-1612)', Oxford Dictionary of National Biography, Oxford University Press, May 2014; online edn, April 2016, accessed 16 August 2017. doi.org/10.1093/ref:odnb/105818.

31 Starr Douglas, 'Smeathman, Henry (1742-1786)', Oxford Dictionary of National Biography, Oxford University Press, Oct 2005; online edn, October 2013, accessed 16 August 2017. doi.org/10.1093/ ref:odnb/93969.

32 Susan Edwards, 'Hughes, John (c. 1816-1889)', Oxford Dictionary of National Biography, Oxford University Press, 2004, accessed 16 August 2017. doi.org/10.1093/ref:odnb/49171. 
west as the monkey puzzle tree. ${ }^{33}$ And Kathleen Drew (1901-1957) was a Manchester-born phycologist, whose work on red algae led Japanese scientists to cultivate seaweed artificially after the nori industry had been severely affected by typhoons in the 1940s. In gratitude, the Japanese set up a memorial to the 'Mother of the Sea' near Uto City, where an annual ceremony is held in her honour. ${ }^{34}$

These global and transnational British connections are further illustrated in the annual updates, published every January, of those who have died in the years since 2001. Among the entries that were published in January 2016, recording the lives of men and women who had expired four years before, were many British-born figures who made their careers in the United States. One such was Alexander Cockburn, who had been born in Cromarty in Scotland, but who moved to America in 1972, where he established a reputation as a radical journalist and social critic, publishing much of his work in the Nation. ${ }^{35}$ Another was the hairdresser Vidal Sassoon, who grew up in Whitechapel in the East End of London, but who spent his later business career in California. ${ }^{36}$ Yet a third was the Manchester-born musician, Davy Jones, who lived in the United States from the 1960s, and was a member of the American pop group The Monkees. ${ }^{37}$ In a similar category was the film director Tony Scott, who began life, like his brother Ridley, in Northumberland, but who made his breakthrough film, Top Gun (1986), in the United States. ${ }^{38}$ But such transatlantic traffic has never been confined to those Britons heading west from the Old World to the New: it has also been in the opposite direction, as some Americans have made their lives and careers in the

33 Sue Shephard, 'Lobb, William (bap. 1809, d. 1863)', Oxford Dictionary of National Biography, Oxford University Press, May 2009; online edn, January 2010, accessed 16 August 2017. doi.org/ 10.1093/ref:odnb/59320.

34 Juliet Brodie, 'Drew [married name Baker], Kathleen Mary (1901-1957)', Oxford Dictionary of National Biography, Oxford University Press, May 2010, accessed 16 August 2017. doi.org/10.1093/ ref:odnb/94193.

35 Godfrey Hodgson, 'Cockburn, Alexander Claud (1941-2012)', Oxford Dictionary of National Biography, Oxford University Press, January 2016, accessed 16 August 2017. doi.org/10.1093/ ref:odnb/105283.

36 Caroline Cox, 'Sassoon, Vidal (1928-2012)', Oxford Dictionary of National Biography, Oxford University Press, January 2016, accessed 16 August 2017. doi.org/10.1093/ref:odnb/106626.

37 Johnny Rogan, 'Jones, David Thomas [Davy] (1945-2012)', Oxford Dictionary of National Biography, Oxford University Press, January 2016, accessed 16 August 2017. doi.org/10.1093/ ref:odnb/104817.

38 Justin Smith, 'Scott, Anthony David Leighton [Tony] (1944-2012)', Oxford Dictionary of National Biography, Oxford University Press, January 2016, accessed 16 August 2017. doi.org/ 10.1093/ref:odnb/105447. 
United Kingdom. Among those who died in 2012 were two women journalists: Eve Arnold, who had been born in Philadelphia, and who began her writing career in the United States, but moved to Britain in 1961; and Marie Colvin, who started out in New York, settled in London, became the Sunday Times Middle East correspondent in 1989, and was killed while covering the siege of Homs in Syria. ${ }^{39}$

Although lived out on opposite sides of the Atlantic, all these 'British' lives might properly be described as being Anglo-American, rather than as being bounded by one single nationality. Equally cosmopolitan, although more by necessity than by choice, were the religious and political exiles from Germany and Eastern Europe who settled in Britain during the 1930s. Among those who died in 2012, and whose lives were put up online four years later, were the historian Eric Hobsbawm, who was born in Alexandria in Egypt in 1917, moved from Berlin to London in 1933, and always felt himself to be an outsider, albeit one residing at the heart of the British establishment; he was, appropriately, a pioneer and practitioner of global histories. ${ }^{40}$ Another such figure was the author and feminist Eva Figes, who arrived in Britain from Germany in $1938 .{ }^{41}$ Yet a third was the actor Herbert Lom, who reached Britain from Prague in the following year; he appeared in many of the Ealing Comedies, and also played the part of Inspector Dreyfus alongside Peter Sellers's Inspector Clouseau in the Pink Panther films. ${ }^{42}$ Many Britons have also lived global lives, not as émigrés or exiles, but by virtue of their professions: as soldiers, diplomats, proconsuls, or businessmen. One such figure who died in 2014 was Sir Rex Hunt, who was born in Redcar in Yorkshire, and after a succession of diplomatic postings, mostly in the Far East, served as governor of the Falkland Islands between 1980 and 1985. When the Argentinians invaded, he was expelled to Uruguay, but later returned once

39 Beeban Kidron, 'Arnold [née Cohen], Eve Deborah (1912-2012)', Oxford Dictionary of National Biography, Oxford University Press, January 2016, accessed 16 August 2017. doi.org/10.1093/ ref:odnb/104539; Lindsey Hilsum, 'Colvin, Marie Catherine (1956-2012)', Oxford Dictionary of National Biography, Oxford University Press, January 2016, accessed 16 August 2017. doi.org/ 10.1093/ref:odnb/106518.

40 Martin Jacques, 'Hobsbawm, Eric John Ernest (1917-2012)', Oxford Dictionary of National Biography, Oxford University Press, January 2016; online edn, April 2016, accessed 16 August 2017. doi.org/10.1093/ref:odnb/105680.

41 Eva Tucker, 'Figes [née Unger], Eva (1932-2012)', Oxford Dictionary of National Biography, Oxford University Press, January 2016, accessed 16 August 2017. doi.org/10.1093/ref:odnb/105542. 42 Brian McFarlane, 'Lom, Herbert (1917-2012)', Oxford Dictionary of National Biography, Oxford University Press, January 2016, accessed 16 August 2017. doi.org/10.1093/ref:odnb/105645. 
the islands had been recaptured by the British. ${ }^{43}$ Some 'British' lives are yet more transnational, and are spent in several locations, as in the case of the cricketer Tony Greig: he grew up in South Africa, but played cricket for England, and later worked as a television commentator in Australia. ${ }^{44}$

The combined effects of the continuing and intensifying IT revolution, and of the academic turn towards global and transnational history, means that the $O D N B$ now contains many more entries on lives that are simultaneously British and worldwide than Smith or Stephen could have conceived of in the 1880s - or even than Matthew might have foreseen more than 100 years later. This in turn means the Dictionary may now be used not only as a place to look up individual lives online, but also as a starting point for original research into global networks and transnational life-patterns. Here is one example: Magna Carta is invariably regarded as a defining English event, both in terms of royal politics and the common law; but the entries in the $O D N B$ on those who were involved make plain that there was also an international dimension, not least on account of the overseas property interests of those English magnates who lost out through King John's failed campaigns. In the same way, the Dictionary has recently extended its coverage of the pre-Reformation episcopacy to provide entries on all medieval British bishops, and this makes possible comparative studies of their geographical origins, their movements from one bishopric to another across Europe, and their varied relations with papal and royal authorities. And although not comprehensive, the many entries on Britons employed in South Asia by the East India Company and later in the Indian Civil Service offer a starting point for comparative surveys of the social origins, educational backgrounds, and career development of those ruling imperial cadres and proconsular elites. Place-searching in the $O D N B$ also makes it possible to identify some of those potential networks established in Britain by people born abroad: the Dictionary currently includes entries on more than 200 men and women who grew up in India but were resident in London between 1880 and 1920.

43 David Tatham, 'Hunt, Sir Rex Masterman (1926-2012)', Oxford Dictionary of National Biography, Oxford University Press, January 2016, accessed 16 August 2017. doi.org/10.1093/ ref:odnb/105750.

44 Rob Steen, 'Greig, Anthony William [Tony] (1946-2012)', Oxford Dictionary of National Biography, Oxford University Press, January 2016, accessed 16 August 2017. doi.org/10.1093/ ref:odnb/105873. 
At the same time, the still-unfolding impact of IT holds out the exciting possibility of connecting data in the $O D N B$ to online material generated in other national biographies which the Dictionary has spawned and stimulated across the English-speaking world, thereby linking up entries on particular lives_ of notable Britons, Irish men and women, Americans, Australians, New Zealanders, and Canadians-as they travelled round the globe and settled in different places. A much more ambitious project would be to link up all the data on all the lives that are recorded in these Anglophone biographical dictionaries, so as to allow online searching across them by name or by a category such as a profession. It is now also possible to appreciate more fully the many historic links between the British Isles and mainland Europe, as so many men and women moved back and forth across the English Channel and the North Sea. To that end, the $O D N B$ is beginning to work with the national dictionaries of Sweden, the Netherlands, and Austria, in the hope that similar online links and connections may be made. These partnerships, both Anglophone and European, based on 'the electronic combining of individual national biographical dictionaries', should eventually make it possible to assemble a modern-day version of the sort of 'universal or world biography' that was originally envisaged by Smith, and had been envisioned by the Enlightenment philosophes before him. ${ }^{45}$

Such fully comprehensive dictionaries, and such authentically worldencompassing works, were neither possible nor manageable in eighteenthcentury France or in nineteenth-century Britain; but they were foreseen by Oxford University Press as early as 1987, and they were predicted and welcomed by Matthew eight years later. They are both possible and manageable now. But there is still a great deal that needs to be done to make this happen. The technologies and the politics of linking national biographical dictionaries are more complex and more challenging than might at first sight appear. Even if such obstacles can be overcome, would the end result in fact be a universal compendium of global lives? Many parts of the world have yet to produce any such dictionaries, which means the coverage would be overwhelmingly European and English-speaking, and far from universal. Would the gathering together of such national biographies as have been written do full justice to the transnational nature of many people's existences? Would an aggregated dictionary of preexisting national biographies be an adequate substitute for a dictionary of 
authentically global lives? And will the current reassertion of xenophobic nationalism in so many parts of the globe, and the backlash against globalisation, mean that global history and global biography seem less alluring projects and less appealing prospects than once they did?

These are sombre questions which are difficult to ignore in the era of Donald Trump and Brexit. The cosmopolitan vision and wide-angled perspective which informed the writings of Matthew and Keith Thomas on the $O D N B$ and the greater compilations and combinations to which it might lead, now seem a long time ago and a distant world away. Yet adversity should be a stimulus to greater effort rather than an excuse for narrowing horizons or abandoning ambitions. The tenor and trend of our times may be less friendly to globalisation than it was during the 1990s, and before $9 / 11$ and the financial crash of 2007. But the pursuit and practice of global biography remain important objectives and essential tasks in adding to knowledge and in helping us to better understand our planet and its peoples. 'Posterity', Matthew presciently warned, 'will think us negligent if we do not make what provision we can' for undertaking these tasks and achieving these objectives. More than 20 years on, we have not made as much provision, or as much progress, as we should have done, as we need to do—and as we ought to do. ${ }^{46}$

46 Faber and Harrison, 'Dictionary of National Biography: A Publishing History', 189; Matthew, 'Dictionaries of National Biography', 17; Matthew, Leslie Stephen and the New Dictionary of National Biography, 35. 
This text is taken from 'True Biographies of Nations?': The Cultural Journeys of Dictionaries of National Biography, edited by Karen Fox, published 2019 by ANU Press, The Australian National University, Canberra, Australia.

doi.org/10.22459/TBN.2019.11 